\title{
Japanese rights
}

\section{Washington}

THE Wistar Institute's efforts to patent monoclonal antibodies have run into trouble in Japan and the United Kingdom. Twenty-seven separate challenges have been filed in Japan to a Wistar patent for monoclonals that specifically attack tumour cells. The patent is based on research by Hilary Koprowski and Carlo Croce of the Wistar Institute and was assigned to Wistar by the researchers. And the British Patent Court recently affirmed the rejection by the Patent Office there of a second patent that covers monoclonals specific for viral antigens. Both have been successfully patented in the United States.

The challenge to the tumour antibody patent in Japan may prove the more costly of these setbacks to Wistar. A test kit that makes use of the antibodies for diagnosing solid tumours is already on the market in Japan, and Wistar has already sold three licences to the US patent. Clinical trials of anticancer agents that use the antibodies to home in on tumour cells are under way in the United States. Although Wistar's associate director, Warren Cheston, says that "realistically" he expects the patent to bring in less than $\$ 100,000$ a year to the institute, he acknowledges that "if you believe the people on the commercial side, there's potentially huge sales out there"' Cheston points out that the non-monoclonal diagnostic for colo-rectal cancer now in use is a multi-million dollar market.

Those challenging the patent are basing their case largely on an article that appeared in Nature the day before the US patent application was filed. The US patent is not threatened by the Japanese challenge, but the US filing established the priority date of the invention. And unlike the United States, which allows an inventor to apply for a patent up to a year after disclosing his invention, Japan (like Western Europe) demands "absolute novelty" - no disclosure before the first filing. The patent was filed for in the United States on 28 April 1978; in the 27 April issue of Nature, a News and Views article appeared with a brief description of Koprowski's work.

According to Helmuth Wegner, a Washington patent attorney who is representing one of the challengers, that disclosure, even if it is no more than "a fairly broad suggestion", is enough to invalidate the Japanese patent. The Nature article provides no experimental details; it notes in a single sentence that Koprowski had produced hybridomas that secrete antibodies with tumour-specific activity. The legal issue is whether that disclosure is in theory sufficient to allow someone else to duplicate Koprowski's work with a reasonable amount of experimentation.

Another tricky issue is sure to be the exact date that the Nature disclosure is considered to have taken place. The magazine would have been available in Nature's London office on 26 April, and would have been posted to subscribers on that day. The Japanese law defines disclosure to have occurred when the publication is "distributed", a term not yet tested in court.

The report referred to (Nature 272, 751; 1978 ) is by Dr Elizabeth Simpson of the Medical Research Council's National Institute of Medical Research at Mill Hill, London, and describes the proceedings of a workshop organized by $\mathbf{M}$. Potter and F. Melchers at the National Institutes of Health on 3-5 April 1978. Simpson refers to the production of monoclonal antibodies against "Differentiation and tumour antigens" by "several groups", and says that Koprowski, using human cancer tissues as a source of antigens, had

been able to produce monoclonal antibodies which reacted with human cells so as to "suggest that some of them may be against tumour-specific antigens".

If the challenges are upheld, Wistar would lose the Japanese market, which is the second largest pharmaceutical market in the world. Patents in North America and West Germany would not be affected.

The British patent covered the work by Koprowski, Croce and Walter Gerhard on monoclonal antibodies specific for viral antigens. The Patent Office had earlier ruled that the work was an obvious application of the basic procedures for producing monoclonal antibodies developed several years earlier but never patented by César Milstein and Georges Kohler of the Medical Research Council's Laboratory of Molecular Biology. The Patent Office noted in particular an article that had appeared in The Lancet - before the filing of the Wistar patent - that suggested a number of possible uses for monoclonal antibodies, including the detection of viral antigens. Wistar, which had little difficulty obtaining broad patent protection in the United States and several European countries for the viral antibodies, appealed against the rejection; late last year the patent court ruled in favour of the Patent Office.

Stephen Budiansky

\section{European forests \\ Pollution, pathogens and pests}

FORESTS in the Federal Republic of Germany (FRG) and many other parts of Central Europe are deteriorating rapidly. It is estimated that in West Germany 34 per cent of all forest, which covers 27 per cent of the country's total land area, is already damaged. The city of Augsburg has created a special nature park to inform its citizens about the advancing disaster and the Christmas tree business has languished. Whereas in 1982 damage to conifers was estimated in Bavaria at 10-30 per cent, the official figure is now 60 per cent for Scots pine (Pinus sylvestris) and 80 per cent for fir (Abies). Furthermore, 44 per cent of the beech forest is showing signs of distress.

The situation in Switzerland, where the first symptoms were reported at the Federal Institute of Forest Science in early 1983, has deteriorated rapidly, exacerbated by heavy snowfalls and storms in the two previous winters. The first signs of distress were shown by Abies alba in the eastern and northern plateau that includes Berne, the Bodensee and the most heavily populated areas. Three months ago, reports came in from the southern Alps of damage to spruce (Picea excelsa), the dominant species, between 1,000 and 1,800 $m$ altitude and in November of massive damage in some localities.

In Czechoslovakia, 11 per cent of the forest is said to be destroyed and a further 11 per cent dying. A recent ecological report by the Czech Academy of Sciences, which was not published in Czechoslovakia but a copy of which reached the French newspaper Le Monde through the human rights organization Entraide et Action, draws a grim environmental picture that forecasts that $45-60$ per cent of the nation's forest will be degraded by the end of the century.

Although most of the damage is caused by "acid rain", two serious forest pests are adding to the toll. In Switzerland, winter weather damage was followed by an exceptionally hot summer in 1983. Attacks by the bark beetle Ips typographus L. reached serious levels. This beetle normally produces two generations per summer, but in 1983 it produced three. This winter so far has been exceptionally mild and the beetle will overwinter in serious numbers if the normal cold fails to occur. In the stressed environments at high altitudes, regeneration of forest is slow and the Swiss institute is seriously concerned that the threatening deafforestation will lead to erosion and avalanches.

In Poland, the moth Lymanthia monacha (the black arches moth) known in German as Die Nonne (the nun) is said to be the major cause of damage. Historical accounts exist of this moth occurring in devastating swarms from Europe through Central Asia to China and Japan, killing large areas of both conifer and broadleaved forest, until it eventually succumbs to its own disease.

Sarah Tooze 